\title{
Field trials of suction caissons in clay for offshore wind turbine foundations
}

\author{
G. T. HOUlSBY*, R. B. KELlY*, J. HuXTABLE† and B. W. BYRNE*
}

\begin{abstract}
A programme of testing of caisson foundations in clay at the Bothkennar test site is described. The tests are relevant to the design of foundations for offshore wind turbines, in the form of either monopod or tetrapod foundations. Records are presented for installation of the caissons, cyclic moment loading under both dynamic and quasi-static conditions, cyclic inclined vertical loading, and pullout of the caisson. Variation of stiffness of the foundation is observed, with high initial stiffness followed by hysteretic behaviour at moderate loads and degradation of response at high loads. Some implications for the design of wind turbine foundations are briefly discussed.
\end{abstract}

KEYWORDS: bearing capacity; clay; dynamic test; foundations; stiffness
Nous décrivons un programme servant à tester les fondations en caisson dans de l'argile au site d'essai de Bothkennar. Les essais se rapportent à la conception de fondations pour des turbines à vent offshore, de forme monopode ou tétrapode. Nous présentons les résultats concernant l'installation des caissons, le chargement de moment cyclique dans des conditions dynamiques et quasi statiques, le chargement cyclique incliné à la verticale et le décrochage du caisson. Nous observons des variations quant à la rigidité des fondations, avec une rigidité initiale élevée suivie par un comportement hystérétique sous charges modérées et une dégradation de la réponse sous charge élevée. Nous discutons brièvement des implications quant à la conception des fondations des turbines à vent.

\section{INTRODUCTION}

The offshore wind energy industry is a very rapidly expanding sector of vital economic importance in the UK, and foundation costs are an important part of the costs of offshore wind turbine installations (Byrne \& Houlsby, 2003). Most current foundations for offshore wind turbines are large 'monopiles', although some have been founded on gravity bases. However, with the current expansion of the offshore wind energy industry, alternative foundation types are being considered. One possibility is the use of 'suction caisson' foundations (Houlsby \& Byrne, 2000; Byrne \& Houlsby, 2003). Suction caissons are now widely used as anchors for floating structures, and have also been used offshore as foundations for a small number of fixed platforms (Bye et al., 1995). They are large cylindrical structures, open at the base (see Fig. 1). During installation they cut a small distance into the seabed under their own weight, but are then installed to their full depth (with the caisson lid flush with the seabed) by pumping out the water that is trapped within the caisson. They can be installed in either clays or sands. The principal advantage for the offshore wind application is that the caissons can be installed rapidly, using relatively inexpensive equipment.

Methods for designing caisson foundations for offshore wind applications are in their infancy, and in response to the need for design methods a programme of research has been sponsored by the UK Department of Trade and Industry, the Engineering and Physical Sciences Research Council, and a consortium of companies (see Acknowledgements) (Byrne et al., 2002). In this study, design methods are being developed principally on the basis of small-scale model testing (Byrne \& Houlsby, 2002, 2004; Byrne et al., 2003; Kelly et al., 2003, 2004), but an important part of the research is a programme of intermediate-scale field trials to check on the

Manuscript received 22 April 2004; revised manuscript accepted 24 January 2005.

Discussion on this paper closes on 1 November 2005, for further details see p. ii.

* Department of Engineering Science, University of Oxford.

$\dagger$ Fugro Structural Monitoring Ltd, Glasgow.

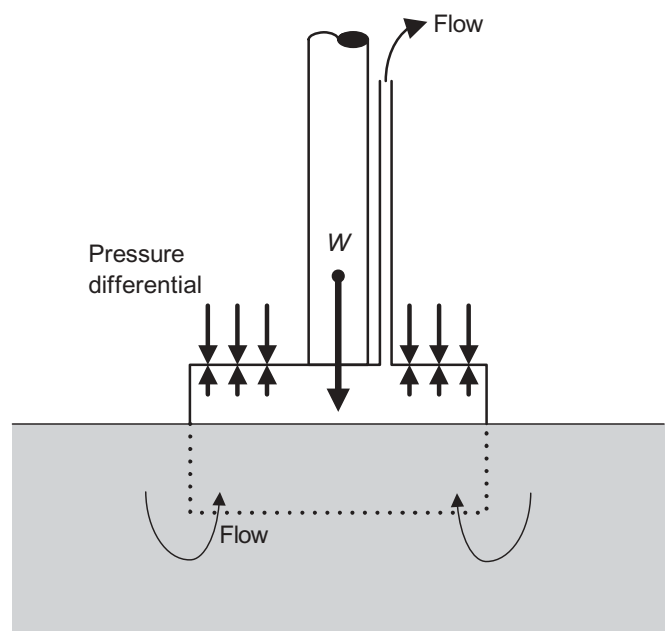

Fig. 1. Installation of a suction caisson

scalability of the results. In this paper, tests on $1.5 \mathrm{~m}$ and $3.0 \mathrm{~m}$ diameter caissons at the Bothkennar test site are reported. Typical sizes of prototype caissons are discussed below. Other studies of design methods for suction caissons for foundation (as opposed to anchor) applications have concentrated on analytical procedures (e.g. Bransby \& Randolph, 1998) or finite element analysis (e.g. Gourvenec \& Randolph, 2003).

A key feature of offshore wind turbine structures is that (for their size) they are relatively light (with a mass of the order of $600 \mathrm{t}$ for a $3.5 \mathrm{MW}$ turbine structure), yet they are subjected to large horizontal forces and overturning moments from wind and waves (Byrne \& Houlsby, 2003). The horizontal load may, for instance, be of the order of $65 \%$ of the vertical load. Thus the challenge to the foundation engineer is to carry large (and repetitive) horizontal loads and overturning moments, but relatively little vertical load. Two main structural configurations using caissons are being considered: either a 'monopod' consisting of a single large caisson (typically $20-25 \mathrm{~m}$ in diameter for a modern large turbine 
structure), or a 'tetrapod' in which the load is transferred through a truss structure to four smaller caissons: see Fig. 2 (preliminary calculations indicate that the obvious alternative of a tripod is a less favourable configuration). Each of the smaller caissons might be, say, $6-8 \mathrm{~m}$ in diameter. For the monopod the most important load on the foundation is the overturning moment. In the case of the tetrapod the moment loading is carried principally by 'push-pull' action by opposing footings, and it is the variation of vertical load (and in particular the possibility of tension on a footing) that is most important. In both cases the design objective is to select an appropriate diameter $D$ and depth $h$ of the caisson, and in the tetrapod case the spacing $s$ must also be determined (see Fig. 2).

The testing programme described below includes tests directed towards the design of both the monopod and the tetrapod. Data were obtained from the installation phases for each caisson. Loading of the caissons was by means of a combination of dead weights, hydraulic jacks and inertial loading from a structural eccentric mass vibrator (SEMV).

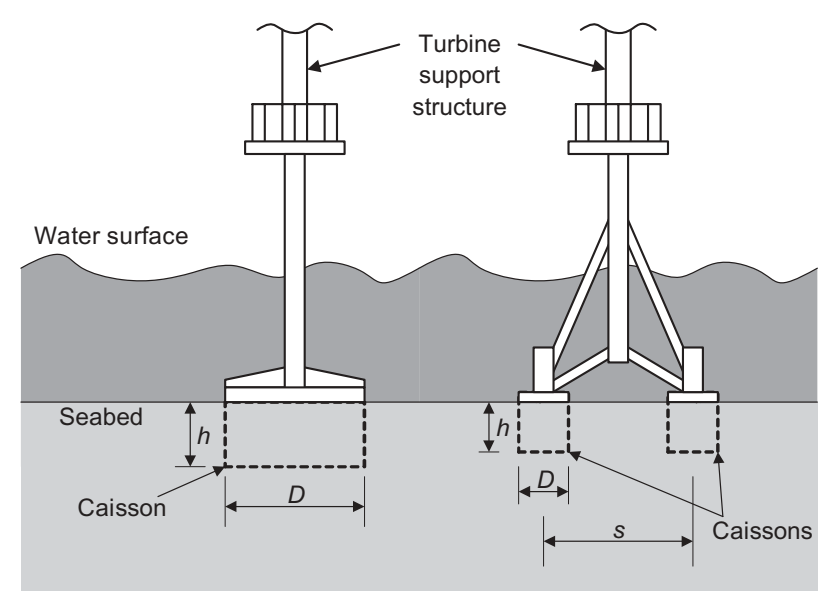

Fig. 2. Possible configurations for suction caisson foundations for wind turbines
The test programme was designed by Oxford University, and site operations were managed by Fugro Structural Monitoring Ltd. The tests were carried out in December 2003 and January 2004.

\section{EQUIPMENT AND TESTING PROCEDURES}

The caissons were fabricated from mild steel, with the principal dimensions given in Table 1. The lids of the caissons were stiffened by I-sections. Ports were provided for attaching the pump and for venting the caissons. An Aframe structure was attached by pins to the $3.0 \mathrm{~m}$ caisson to transfer loads from the SEMV or hydraulic jack. Load cells were fitted to measure the axial load in all four legs of the frame.

Reaction loads for testing were provided by a steel frame, and the layout of the entire testing assembly is shown in Fig. 3. The reaction frame was supported on two square foundations $(2 \mathrm{~m} \times 2 \mathrm{~m} \times 1 \mathrm{~m}$ deep $)$, which were also installed by the suction method. The frame was installed in a pit of depth approximately $1.5 \mathrm{~m}$ at the Bothkennar test site: see Fig. 4. Details of the soil properties at Bothkennar are reported in the collection of papers in Géotechnique, Vol. 42, No. 2 (June 1992). The best estimate is that the base of the pit corresponds to a depth of $1.75 \mathrm{~m}$ in Nash et al. (1992), so that the undrained shear strength (measured by the undrained triaxial test), taken from the figures in Nash et al. (1992), is $s_{\mathrm{u}}=11.43+1.9 z$, where $s_{\mathrm{u}}$ is in $\mathrm{kPa}$ and $z$ is the depth in metres below the base of the excavation. Salient values are therefore $s_{\mathrm{u}}=11.4 \mathrm{kPa}$ at the soil surface, $13.4 \mathrm{kPa}$ at the base of the $1.5 \mathrm{~m}$ caisson, and $14.4 \mathrm{kPa}$ at the base of the $3.0 \mathrm{~m}$ caisson. The bulk density of the clay at relevant depths is estimated as $1680 \mathrm{~kg} / \mathrm{m}^{3}$. Throughout the testing period the base of the test pit was covered by about $0.25 \mathrm{~m}$ of water. The vertical bearing capacities of the small and large caissons were estimated (using the method of Houlsby \& Martin, 2003) as $164 \mathrm{kN}$ and $746 \mathrm{kN}$ respectively.

In addition to the clevis pin load cells at the base of the A-frame on the $3.0 \mathrm{~m}$ caisson, loads applied by all hydraulic

Table 1. Details of caisson dimensions

\begin{tabular}{c|c|c|c|c}
\hline Diameter: $\mathrm{m}$ & $\begin{array}{c}\text { Skirt length: } \\
\mathrm{m}\end{array}$ & $\begin{array}{c}h / D \\
\text { ratio }\end{array}$ & $\begin{array}{c}\text { Wall thickness: } \\
\mathrm{mm}\end{array}$ & $\begin{array}{c}\text { Approximate mass: } \mathrm{kg} \\
\text { (including appurtenances) }\end{array}$ \\
\hline 1.5 & 1.0 & 0.67 & 8 & 670 \\
3.0 & 1.5 & 0.5 & 8 & 2000 \\
\hline
\end{tabular}

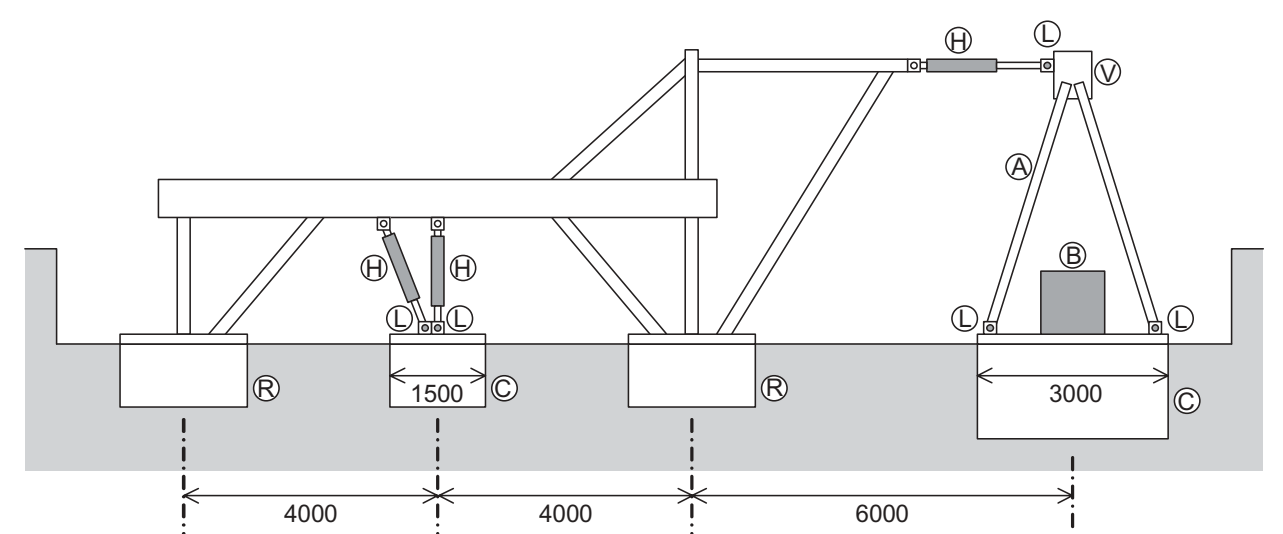

(a)

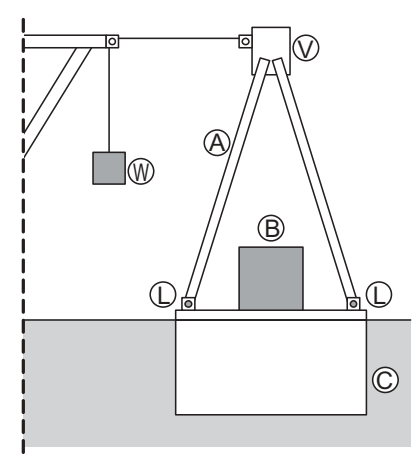

(b)

Fig. 3. Outline of field testing equipment, dimensions in $\mathrm{mm}$ (water in excavation and displacement reference frames not shown): (a) arrangement for jacking tests on $1.5 \mathrm{~m}$ and $3.0 \mathrm{~m}$ caissons; (b) alternative arrangement during SEMV tests. Labels indicate (A) Aframe, (B) concrete block, (C) caissons, (H) hydraulic jacks, (L) load cells, (R) foundations of reaction frame, (V) SEMV, (W) weight providing offset load for SEMV tests 


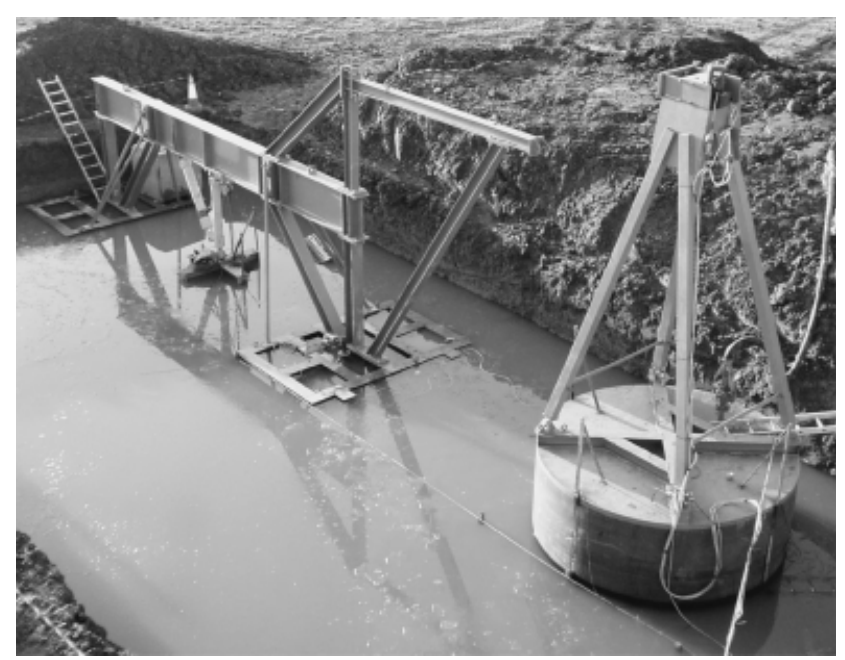

Fig. 4. Test rig, showing the $1.5 \mathrm{~m}$ caisson installed and $3.0 \mathrm{~m}$ caisson in place for installation

jacks used in the testing were measured by further load cells. Displacements of the caissons were measured by drawwire transducers attached to a scaffold frame based at least $1.5 \mathrm{~m}$ away from the outside of the caisson. The draw-wires were attached to the caisson via upstand frames to keep the transducers clear of the water. Six transducers were used to resolve all six degrees of freedom of movement. The coordinates of the transducers were first determined using surveying techniques. During SEMV tests, displacements were also monitored by means of accelerometers. One pore water pressure transducer was fixed centrally to the underside of the lid of each caisson, and two more on the inside of the caisson just above the base of the skirt (at opposite ends of a diameter). The general layout of the instrumentation is shown in Fig. 5. All transducer data were logged at $50 \mathrm{~Hz}$ for most tests, with averages over 50 readings used for further analysis, and at $400 \mathrm{~Hz}$ for the SEMV tests (without data averaging).

The caissons were installed according to the following procedure:

(a) The caisson was lowered to the soil surface and allowed to penetrate under its own weight, with the interior vented to atmosphere.

(b) Water was pumped into the caisson until it was full.

(c) The vent was closed, and water was pumped out of the caisson to install it to full depth.

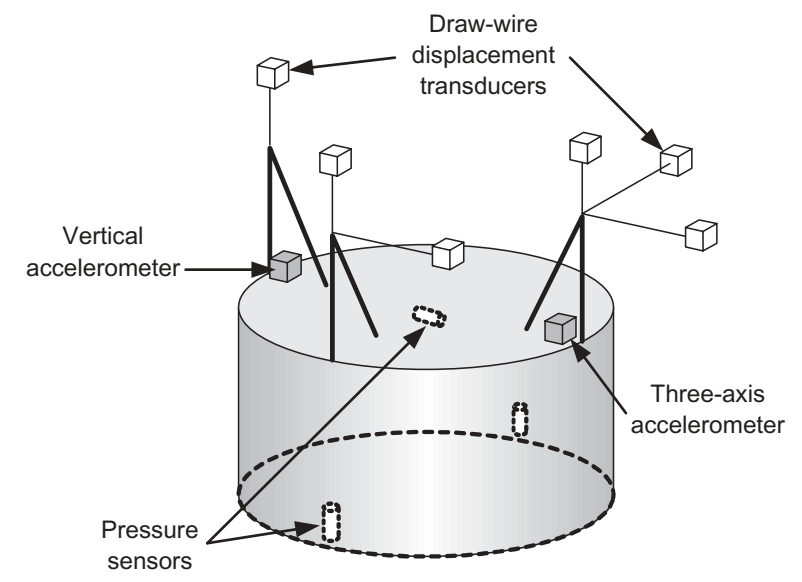

Fig. 5. Outline of instrumentation on caisson (draw-wire transducer reference frame not shown)
During phase $(c)$ dead weights were added to the caisson to correct (as far as possible) any errors in levelling of the caisson. All subsequent testing (except where noted) was carried out with the caisson vents sealed.

The tests on the $3.0 \mathrm{~m}$ caisson were relevant to a monopod. Small-amplitude cyclic horizontal loads were applied at the top of the A-frame $(4.23 \mathrm{~m}$ above the lid of the caisson) by means of the SEMV, operating at $10 \mathrm{~Hz}$, at which frequency the applied load was $\pm 5.0 \mathrm{kN}$. These loads are intended to be representative primarily of wave loads experienced by a prototype structure, but scale to waves of different magnitudes (and return periods) for different sizes of prototype. No attempt has been made to scale the wave frequency, as undrained conditions are assumed in both test and prototype, and dynamic effects may be accounted for as discussed below. A fixed bias to the horizontal loading (representing a wind and/or current loading) was achieved by suspending a $400 \mathrm{~kg}$ block from a pulley system attached to the top of the A-frame (see Fig. 3(b)). The vertical load on the caisson throughout these tests was augmented by a $2400 \mathrm{~kg}$ concrete block. During the first series of SEMV tests an interesting observation was that, while the caisson moved only imperceptibly, vibration at $10 \mathrm{~Hz}$ transmitted through the ground set up a resonance in the scaffold reference frame for displacement measurement (thus effectively rendering the displacement measurements useless). This could not be eliminated satisfactorily by stiffening the frame, and in subsequent SEMV tests displacements were measured by accelerometers attached directly to the caisson.

A second set of tests on the $3.0 \mathrm{~m}$ caisson involved largeamplitude (but low-frequency) cyclic horizontal loading from a hydraulic jack placed approximately horizontally between the top of the A-frame and the main reaction frame (Fig. 3(a)). The amplitude of the loads was steadily increased until large $(>200 \mathrm{~mm})$ movements of the loading point occurred. These tests were principally intended to assess the performance of the caisson under extreme conditions.

The tests on the $1.5 \mathrm{~m}$ caisson were relevant to the tetrapod design. It was first loaded to a fixed vertical load by means of a hydraulic jack. Cyclic inclined loading was then applied using a second jack (inclined at 2:1 to the horizontal). Packets of 10 cycles of increasing load amplitude were applied. The intention was that during these cycles the load in the vertical jack would be held constant, but the stiffness of the hydraulic system rendered it difficult to control this load, which therefore showed significant fluctuations. At the end of the testing the inclined jack was disconnected, and the caisson was pulled out rapidly by the vertical jack to assess the ultimate tensile capacity.

After the tests were completed the caissons were removed from the ground simply by reversing the installation process: that is, by reconnecting the pump and pumping water back into the caisson. The $1.5 \mathrm{~m}$ and $3.0 \mathrm{~m}$ caissons were each installed and tested at two locations in the same test pit at Bothkennar: a brief summary of the tests completed is given in Table 2.

\section{TEST RESULTS \\ Installation}

Figure 6 shows the records of measured suction against penetration depth for two installations of the $3.0 \mathrm{~m}$ caisson and one of the $1.5 \mathrm{~m}$ caisson. Interruptions to the applied suction have been removed from the records for clarity. It can be seen that the variation of suction with depth is reasonably repeatable for the $3.0 \mathrm{~m}$ caisson. Also shown on the figure are the computed profiles of suction, using the procedure described by Houlsby \& Byrne (2005) (modified slightly to account for the fact that the caisson is not entirely 
Table 2. Outline of caisson tests carried out at Bothkennar

\begin{tabular}{|c|c|c|c|c|}
\hline Caisson & Installation & Test type & Code & Notes \\
\hline $1.5 \mathrm{~m}$ & 2 & $\begin{array}{l}\text { Installation } \\
\text { Jacking test } \\
\text { Pull out } \\
\text { Installation } \\
\text { Jacking test } \\
\text { Pull out }\end{array}$ & $\begin{array}{l}\text { Inst_1 } 1 \cdot 5 \_1 \\
\text { Jack_1 } 5 \_1 \\
\text { Pull_1 } \\
\text { Inst_1 } 5 \_2 \\
\text { Jack_1 } 5 \_2 \\
\text { Pull_2 }\end{array}$ & $\begin{array}{l}\text { No suction data } \\
\text { Inclined jack attached, but } \\
\text { not pressurised }\end{array}$ \\
\hline $3.0 \mathrm{~m}$ & 1 & $\begin{array}{l}\text { Installation } \\
\text { SEMV tests } \\
\text { Jacking test } \\
\text { Installation } \\
\text { SEMV tests } \\
\text { Jacking test }\end{array}$ & $\begin{array}{l}\text { Inst_3·0_1 } \\
\text { SEMV_1_1 } \\
\text { SEMV_1_2 } \\
\text { SEMV_1_3 } \\
\text { Jack_3·0_1 } \\
\text { Inst_3·0_4 } \\
\text { SEMV_2_1 } \\
\text { SEMV_2_2 } \\
\text { Jack_3.0_2 }\end{array}$ & $\begin{array}{l}\text { No accelerometer data } \\
\text { No accelerometer data } \\
\text { No accelerometer data } \\
50 \mathrm{~Hz} \text { logging }\end{array}$ \\
\hline
\end{tabular}

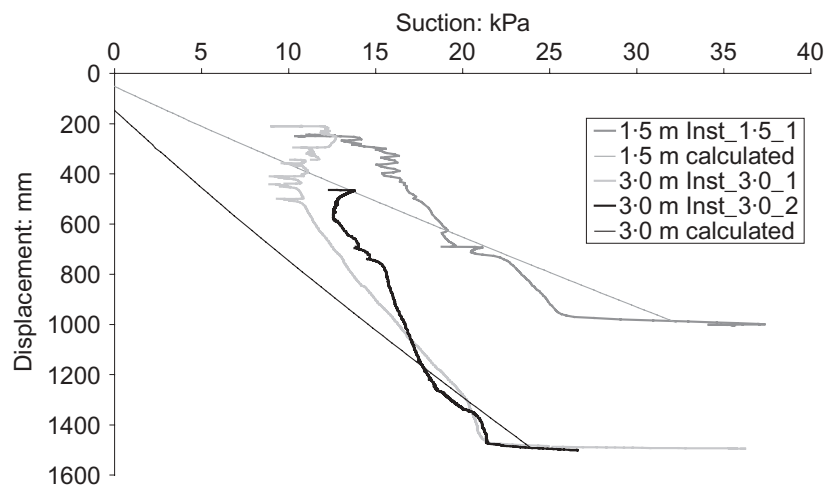

Fig. 6. Records of suction during penetration

submerged). The calculations used the strength profile quoted in the previous section, together with an adhesion factor $\alpha=0.5$ both inside and outside the caisson and $N_{\mathrm{c}}=9$ on the rim of the caisson.

It can be seen that, in general, the computed suction pressure agrees well with the observations as the full depth of the caisson is approached, but underestimates the suction at shallower depths. The most probable explanation is that the fitted strength profile from Nash et al. (1992) is appropriate principally for depths greater than about $3.5 \mathrm{~m}$ from original ground surface (i.e. $z>1.75 \mathrm{~m}$ approximately). At shallower depths the evidence from vane tests (Nash et al., 1992) is that the strength increases significantly, probably because of past desiccation. The strength of the shallow soil is probably underestimated in the calculation, leading in turn to an underestimation of the suction.

\section{Vibration tests on $3.0 \mathrm{~m}$ caisson}

Figure 7 shows the record of the applied moment (deduced from the load cells in the legs of the A-frame) against time for an SEMV test. The test starts at an offset moment of approximately $16.6 \mathrm{kNm}$ (from the block and pulley system shown in Fig. 3(b)). As the eccentric mass on the SEMV starts to rotate, it exerts an inertial force at the top of the A-frame, which varies with the square of the angular velocity. The amplitude of loading therefore builds up steadily with the frequency, with a minor fluctuation at about $7 \mathrm{~Hz}(t \approx 11 \mathrm{~s}$ in Fig. 7$)$ owing to a resonance of the suspended mass providing the offset moment.

Figure 8 shows the resulting moment-rotation response. The initial small-amplitude cycles (at low frequency) plot as the densely packed curves in the centre of the diagram,

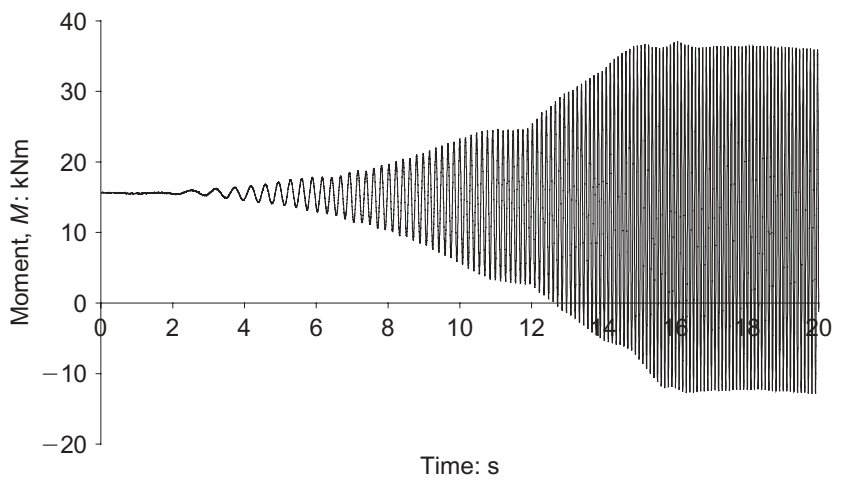

Fig. 7. Moment against time for initial phase of test SEMV_2_2

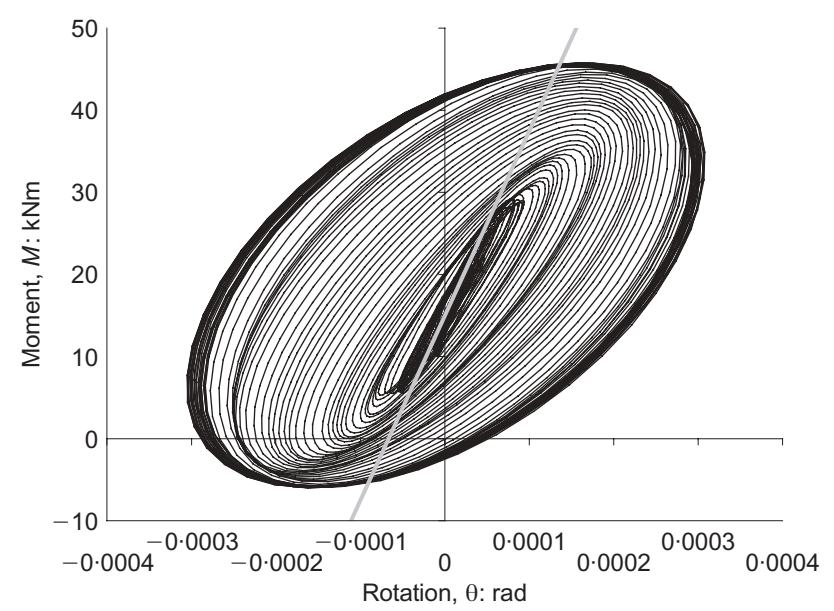

Fig. 8. Moment-rotation response of caisson in test SEMV_2_2

showing a high stiffness and relatively little hysteresis. The line through the data shows a rotational stiffness of $225 \mathrm{MN} \mathrm{m} / \mathrm{rad}$. As the amplitude of moment increases, the moment-rotation loop opens up gradually until the steady state of $10 \mathrm{~Hz}$ cycling is reached, at which stage an approximately elliptical loop (the outer loop in the diagram) is continually retraced. The open loop arises from damping, which has three possible causes:
(a) viscous material damping
(b) plastic dissipation of energy in the soil
(c) radiation damping.

The data can be interpreted by first taking the Fast Fourier 
Transform (FFT) of both the moment and rotation to convert to the frequency domain, and then taking the ratio between the two FFTs to obtain the complex, frequency-dependent impedance. The real part of the impedance represents the stiffness and inertial effects, and the imaginary part the damping. The main information on the effects of frequency on the response is contained within the transients at the beginning and end of the test, and Fig. 9 shows the real and imaginary parts of the transfer function computed for two $20 \mathrm{~s}$ periods covering these transients. Also shown at $10 \mathrm{~Hz}$ are the real and imaginary components computed directly from the steady-state response.

The data may be compared with theories for the behaviour of a circular foundation on an elastic material. Wolf (1994) describes two lumped-parameter models for this case. Wolf presents models for both surface and embedded footings. While recognising that the caisson is in fact embedded into the soil, we use here a preliminary analysis based on factors for surface footings. The analysis of embedded footings requires consideration of cross-coupling between moment and horizontal loading terms, and these coupling effects differ for the stiffness and damping. Furthermore, the role of the inertial terms in the rocking mode is not fully resolved. The principal effect of ignoring the footing embedment is that, in the following, the stiffness coefficients may be underestimated (by a factor that may be in the region of 1.5 , but depending on the assumptions about interactions on the side of the caisson, and the variation of stiffness with depth), and the shear modulus correspondingly overestimated. While this affects the absolute values of the moduli discussed below, it does not affect their relative values.

Wolf's first model is a three-parameter model represented conceptually by Fig. 10(a). For a rigid circular footing at the surface of an elastic soil subjected to moment loads, so that $F \equiv M$ (the applied moment) and $u \equiv \theta$ (the corresponding rotation), the rotational stiffness is

$$
k=\frac{8 G R^{3}}{3(1-v)}
$$

where $G$ is the shear modulus and $v$ is Poisson's ratio. The damping and mass coefficients are calculated by

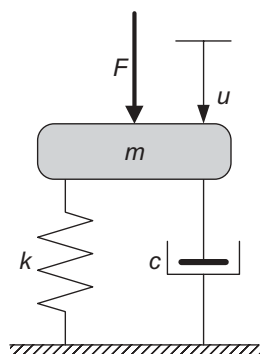

(a)

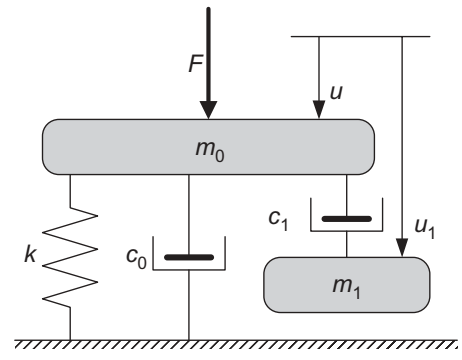

(b)
Fig. 10. Conceptual models for stiffness, damping and mass of a foundation: (a) three-parameter model; (b) five-parameter model

$$
c=\gamma \frac{R}{v_{s}} k
$$

and

$$
m=\mu \frac{R^{2}}{v_{s}^{2}} k
$$

where $\gamma$ and $\mu$ are dimensionless coefficients and $v_{\mathrm{s}}=$ $\sqrt{G / \rho}$ is the shear wave velocity ( $\rho$ is the clay density). Note that, although the soil is assumed to be purely elastic, there is loss of energy through 'radiation damping', which accounts for transmission of energy away from the foundation to an infinitely distant boundary. Adapting the methods of Wolf (1994) and Das (1993) suggests the values $\gamma=0 \cdot 242$ and $\mu=0 \cdot 24$. The real part of the impedance is $k-\omega^{2} m$ and the imaginary part is $\omega c$, and these are shown in Fig. 9 for comparison with the data, computed for $G=12.5 \mathrm{MPa}$. Examining first the real part, the theory provides a reasonable fit to the data at low frequency, but overestimates the stiffness at higher frequencies: this is because the higher frequencies involved higher-amplitude cycling, for which the secant shear stiffness of the soil would be expected to reduce.

Wolf (1994) suggested the alternative five-parameter model shown conceptually in Fig. 10(b) as a more accurate representation of the foundation behaviour. The stiffness $k$ is

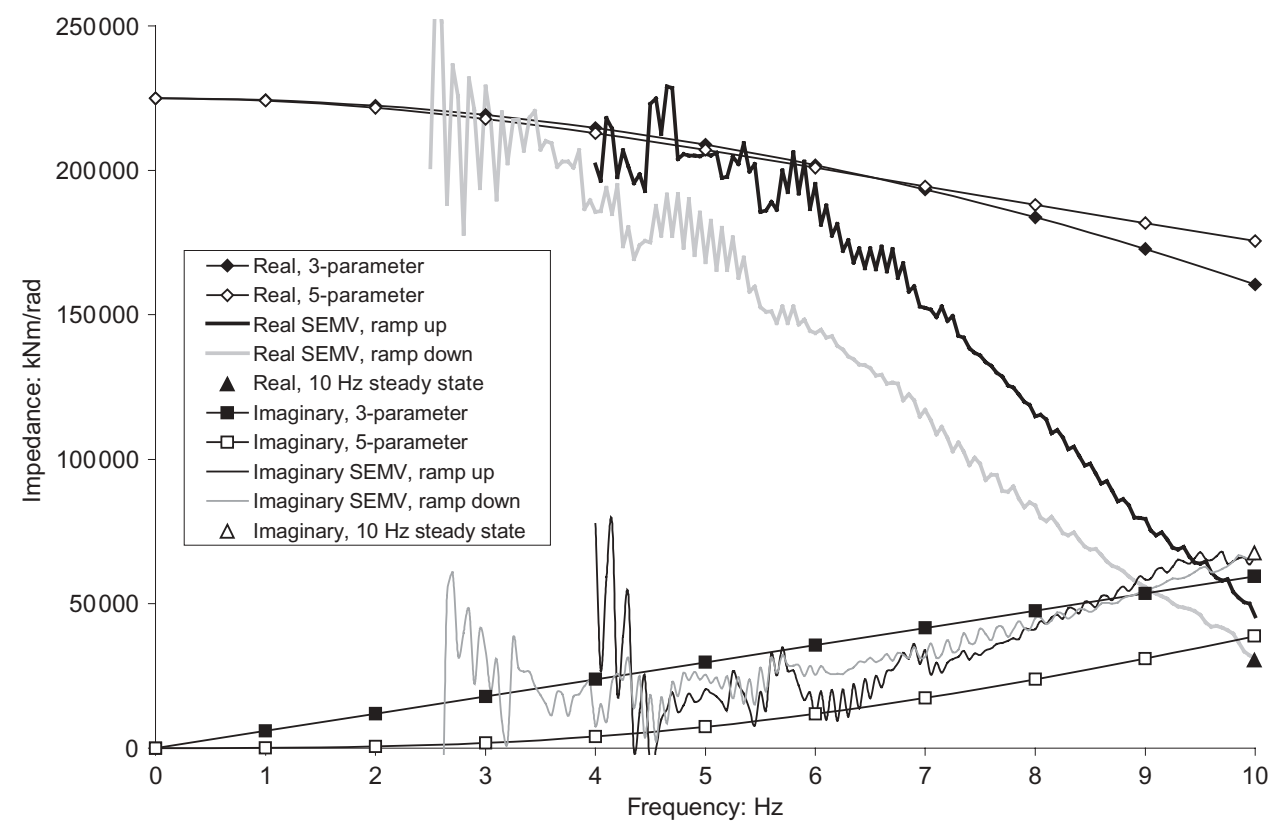

Fig. 9. Complex $\theta-M$ transfer function for test SEMV_2_2 compared with theoretical expressions for three- and five-parameter models 
as for the three-parameter model, and damping and mass coefficients are defined in a similar way to those in the three-parameter model, but with suggested values for $v=0.5 \quad$ of $\gamma_{0}=0, \quad \mu_{0}=0.0267, \quad \gamma_{1}=0.345, \quad \mu_{1}=0.29$. (Note that for the moment-rotation case the general fiveparameter model thus effectively reduces to a four-parameter model.) In this case the real and imaginary parts of the impedance can be calculated as

$$
k\left(1-\frac{a^{2} \mu_{1}}{1+a^{2} \mu_{1}^{2} / \gamma_{1}^{2}}-a^{2} \mu_{0}\right)
$$

and

$$
a k\left(\frac{a^{2} \mu_{1}^{2}}{\gamma_{1}\left(1+a^{2} \mu_{1}^{2} / \gamma_{1}^{2}\right)}+\gamma_{0}\right)
$$

where $a=\omega R / v_{\mathrm{S}}$ is the dimensionless angular velocity. Fig. 9 shows that the five-parameter model gives a very similar variation of the real part of the impedance to the threeparameter model. However, within the range of frequencies tested it gives a lower imaginary part (which represents the damping).

Comparing with the data, it is clear that, in order to fit the real part of the impedance, the stiffness of the foundation would have to be reduced as the frequency increased (and the amplitude of loading increased). Of course this reduction in stiffness is accompanied by an increase in the material damping, which is not taken into account by this model. One therefore expects the damping (imaginary part of the impedance) to be underestimated at higher frequencies by the simple elastic model. The five-parameter model therefore provides a better representation of the real behaviour, as this underestimates the damping. It is worth noting that, although the rotation of the caisson during steady-state cycling is very closely fitted by a $10 \mathrm{~Hz}$ sinusoid, the moment contains significant higher frequencies, with the $20 \mathrm{~Hz}$ component being about $15 \%$ of the amplitude of the $10 \mathrm{~Hz}$ fundamental. Such a response is indicative of non-linearities (such as plastic dissipation) not accounted for in the simple three- or five-parameter models.

\section{Jacking tests on $3.0 \mathrm{~m}$ caisson}

Following the SEMV tests, the $3.0 \mathrm{~m}$ caisson was subjected to further cycles of moment, but under quasi-static conditions, by loading with a hydraulic jack (Fig. 3(a)). Fig. 11(a) shows an example of the resulting moment-rotation curve for the first few, small-amplitude, cycles of test Jack_3.0_2, showing significant hysteresis even at this stage. Fig. 11(b) shows the continuation of the same test to larger amplitude, demonstrating that not only does hysteresis increase with amplitude, but also there is a degradation of the stiffness over several cycles of loading. The degraded response does, however, appear to be gradually stabilising.

Figure 12 shows very large amplitude cycles from test Jack_3.0_1. These cycles are largely of curiosity value, because at such large displacements a full-size foundation would have 'failed' for all practical purposes. It is worth noting, however, the characteristic shape of the cycles, in which, after an initially stiff unloading, a very flexible response is observed, followed by a slight stiffening. This behaviour is typical of a 'gapping' response in which the stiffening occurs as a gap (created by the previous half cycle) is closed. Indeed gaps several tens of millimetres wide and up to $1.02 \mathrm{~m}$ deep were measured down the side of the caisson during these cycles.

The SEMV and jacking tests may be compared as follows. At each frequency the real part of the impedance can be used to deduce a secant shear stiffness of the soil. By making use of the fact that the SEMV applies a load proportional to the square of the frequency, an amplitude of loading can also be attributed to each frequency. Dividing the amplitude of loading by the impedance allows an amplitude of rotation to be determined. Hence the secant

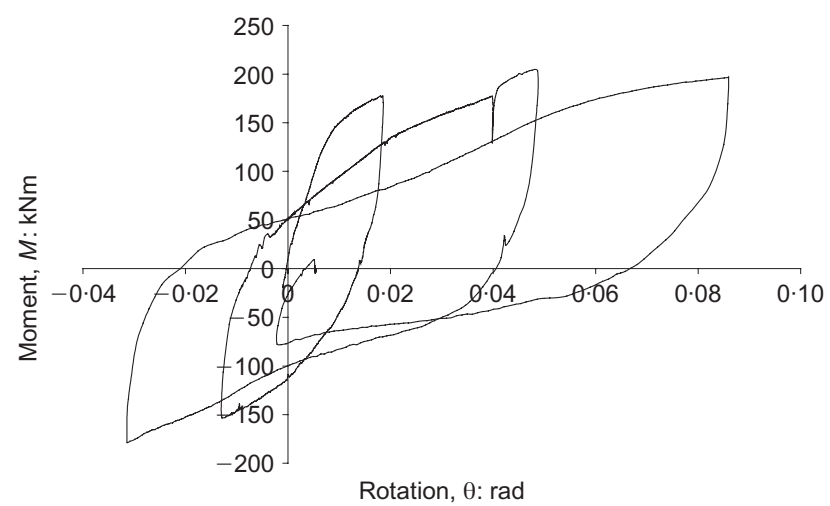

Fig. 12. Moment-rotation curve for loading of $3.0 \mathrm{~m}$ caisson, test Jack_3·0_1: large-amplitude cycles

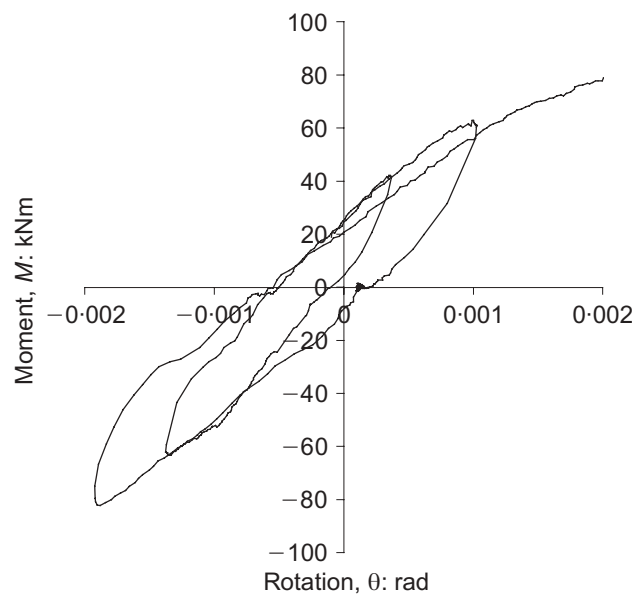

(a)

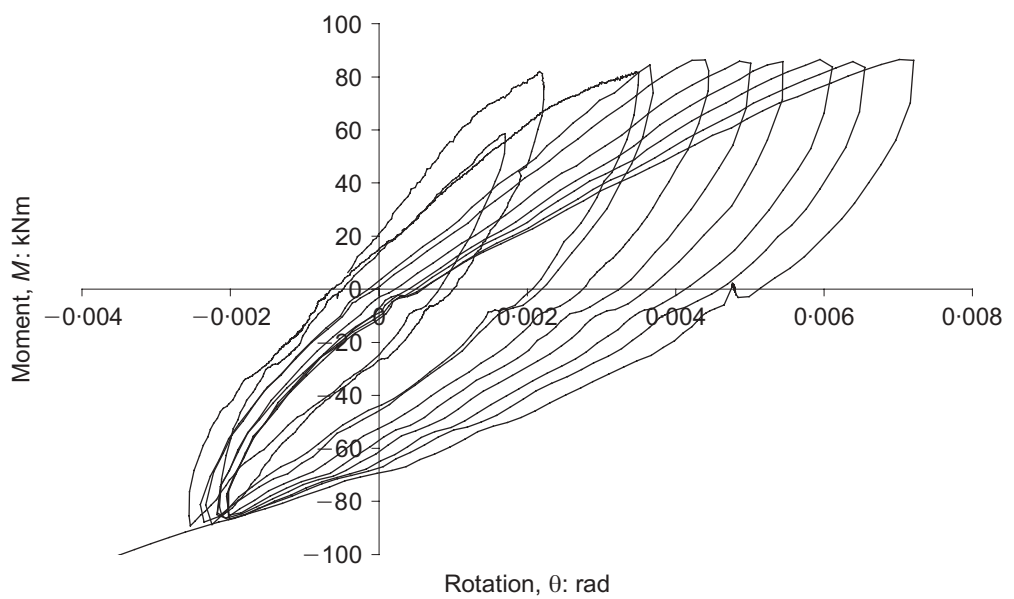

(b)

Fig. 11. Moment-rotation curve for loading of 3.0 m caisson, test Jack_3•0_2: (a) detail of small-amplitude cycles; (b) mediumamplitude cycles 


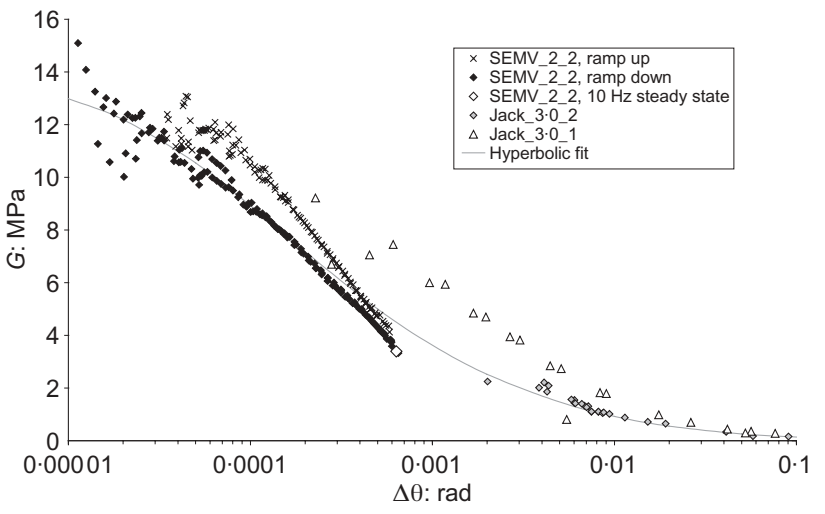

Fig. 13. Computed secant shear modulus from test SEMV_2_2 and jacking tests on $3.0 \mathrm{~m}$ caisson

stiffness can be expressed as a function of amplitude of rotation. The results are shown in Fig. 13, with the set of points for the initial ramp up showing slightly higher stiffness than the ramp down, possibly because some degradation of stiffness is attributable to the cycling. Also shown in the figure is a single point deduced from the steady-state conditions: the confidence attached to this value is much higher than for any of the other data, because it is based on many more readings. It is, however, entirely consistent with the transient data.

Also shown in Fig. 13 are the secant stiffness values from jacking test Jack_3.0_2 (conducted immediately after SEMV_2_2), and Jack_3.0_1 (conducted during an earlier installation of the caisson). These are consistent with the SEMV data in that they show a continuing reduction of the stiffness with increasing amplitude of cycling; indeed, the shape of the $\log (\Delta \theta)-G$ curve is very similar to the familiar pattern for variation of stiffness with strain on a $\log (\Delta \gamma)-G$ plot. The rotation of the caisson is of course approximately proportional to the shear strain amplitude in the soil. Test Jack_3.0_1 shows a somewhat higher stiffness than Jack_3.0_2, probably because better control of level was achieved during installation of this caisson, so that a better contact between the soil and the lid of the caisson was probably achieved. (In practice it is likely that any void between the soil and the lid would be grouted to ensure best performance of the caisson.) Finally Fig. 13 shows a simple fit to the variation of the secant shear stiffness based on the hyperbolic moment-rotation relation

$$
\frac{m}{k_{0} \theta}=\frac{M_{\max }-M}{M_{\max }+A M}
$$

where $k_{0}$ is the initial value of the rotational stiffness, $M_{\max }$ is the maximum moment, and $k_{0} / k_{50}=2+A$, where $k_{50}$ is the secant rotational stiffness at half the maximum moment. The curve is constructed for $k_{0}=252 \mathrm{MNm} / \mathrm{rad}$ (corresponding to $G_{0}=14 \mathrm{MPa}$ ), $M_{\max }=135 \mathrm{kNm}$ and $A=8$.

As mentioned above, a more accurate interpretation of the moment loading tests could be made by accounting for the embedment of the foundation in the calculation of stiffness factors (e.g. Doherty \& Deeks, 2003), but this would simply reduce the absolute values of the estimated stiffness, and not significantly change the relative values or the overall interpretation of the pattern of response.

\section{Jacking tests on $1.5 \mathrm{~m}$ caisson}

The $1.5 \mathrm{~m}$ caisson was first loaded to approximately $120 \mathrm{kN}$ by the vertical jack, and then subjected to cyclic loading from the inclined jack. Because of practical difficul-

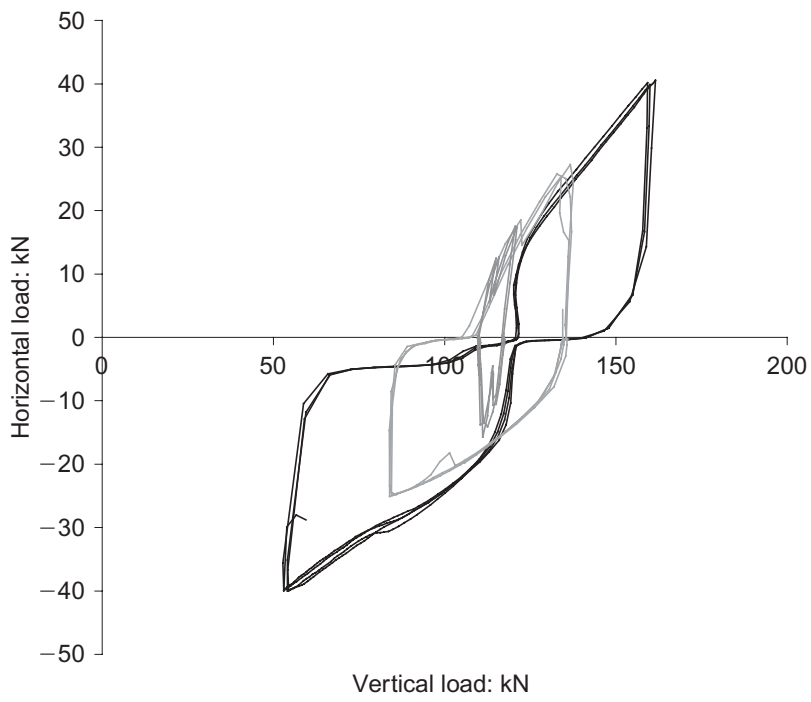

Fig. 14. Load path in cyclic inclined loading test Jack_1.5_2 on $1.5 \mathrm{~m}$ caisson

ties with simultaneous control of pressures in two hydraulic jacks the load path was not, however, a simple line in $V-H$ space, but involved a rather complex path as shown in Fig. 14 (for clarity in this figure a considerable amount of data has been removed, and the paths are plotted only for a few cycles near the beginning, middle and end of the test). Importantly, however, the path involved the main element of loading in the field, in that horizontal loading is accompanied by changes in vertical loading too: the path was selected to represent a realistic ratio between these changes. Note, however, that in the prototype tetrapod the caisson would be restrained against rotation, whereas in the tests the caisson was free to rotate.

Figure 15(a) shows the horizontal load against displacement for the first few cycles of test Jack_1.5_2. In spite of the complications caused by scatter in data, the hysteresis loops are clear. Fig. 15(b) shows the continuation of the test to a series of packets of 10 cycles at increasing amplitude of load. For the tests up to $H= \pm 30 \mathrm{kN}$ there is very little degradation of response, but the tests at $H= \pm 40 \mathrm{kN}$ show a clear degradation with cycling. Using the bearing capacity factors of Houlsby \& Martin (2003) the computed bearing capacity for the foundation is $163 \mathrm{kN}$, so this degradation may well be due to the bearing capacity of the foundation being reached during the compressive cycles: see Fig. 16.

Figure 16 shows the vertical movements throughout test Jack_1.5_2. During the first few cycles there is very little vertical movement. During the intermediate cycles some vertical downward movement accumulates during the cycling, but rapidly stabilises, and finally the largest cycles cause ongoing significant vertical movements.

It appears therefore that for both horizontal load and moment cycling there is a pattern of stiff response with little hysteresis at very small cyclic loads only. As loads increase the stiffness reduces and hysteresis increases, but the loops are fairly stable. Eventually a load level is reached at which a rapid deterioration of performance with number of cycles is observed.

\section{Pullout tests on $1.5 \mathrm{~m}$ caisson}

At the end of the jacking tests on the $1.5 \mathrm{~m}$ caisson, the caisson was pulled out rapidly by means of the vertical jack. The results for test Pull_1 are shown in Fig. 17. The tensile load decreases rapidly to about $-150 \mathrm{kN}$, and after some 


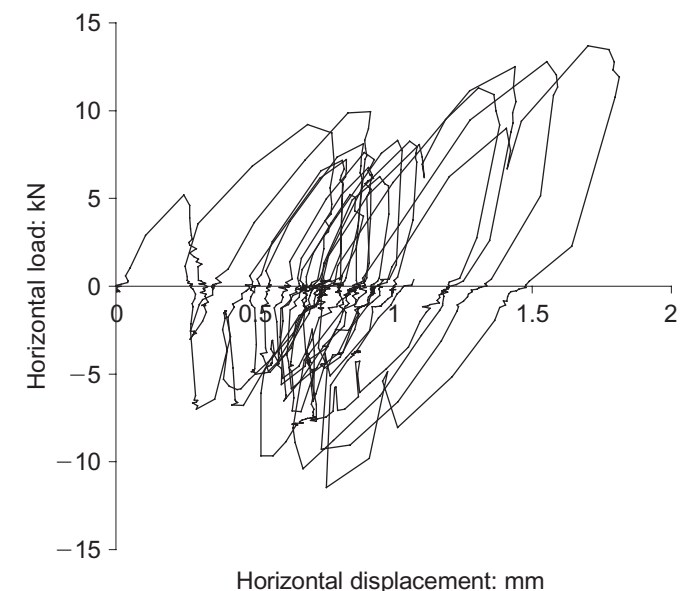

(a)

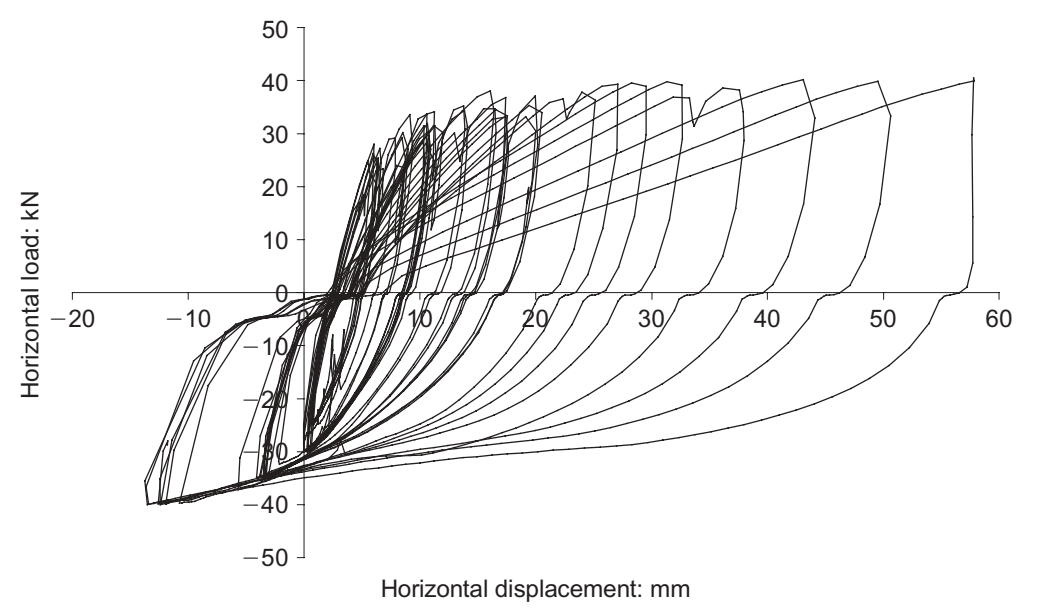

(b)

Fig. 15. Horizontal movement during inclined loading test Jack_1.5_2 on $1.5 \mathrm{~m}$ caisson: (a) detail of small-amplitude cycles; (b) large-amplitude cycles

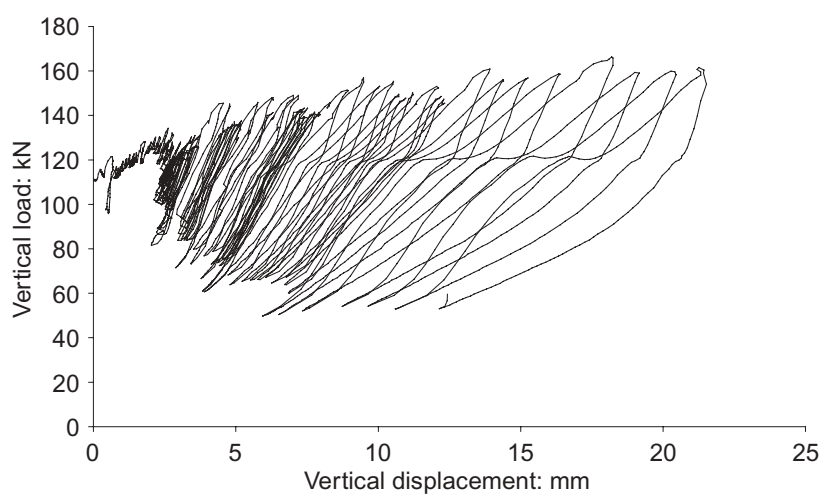

Fig. 16. Vertical movement during inclined cyclic loading test Jack_1.5_2 on $1.5 \mathrm{~m}$ caisson

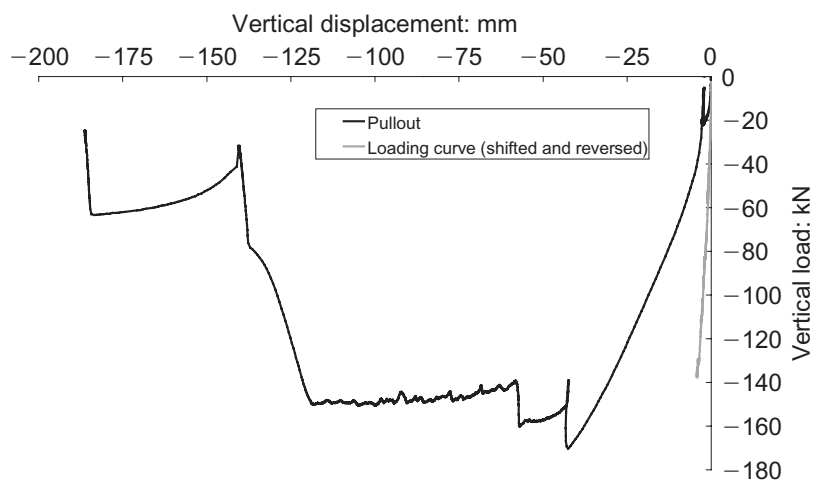

Fig. 17. Load against displacement during pullout test Pull_1

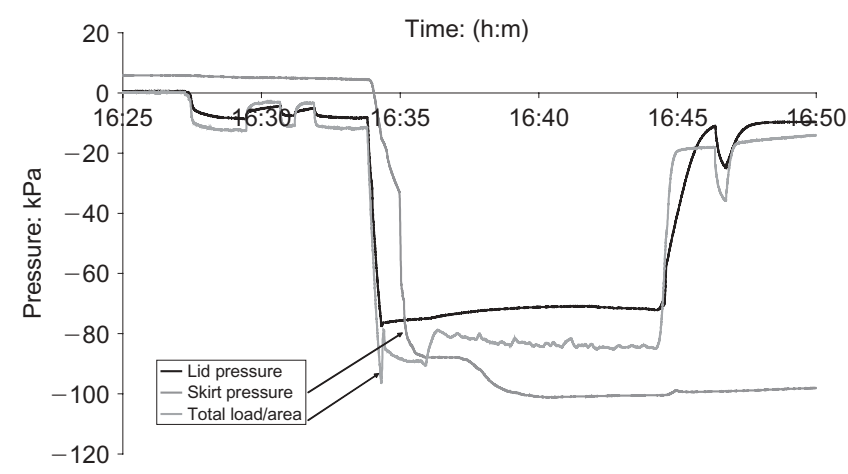

Fig. 18. Record of pullout of $1 \cdot 5 \mathrm{~m}$ caisson, test Pull_1 minor fluctuations pullout occurs at a relatively constant load. Fig. 18 shows the variation with time of pore pressure measured under the lid of the caisson and at the tip of the caisson. Also shown is the total vertical load, converted to the dimensions of pressure by dividing by the area of the caisson. It can be seen that the pore pressure under the lid is approximately $-80 \mathrm{kPa}$ (relative to atmospheric pressure) throughout pullout, indicating that cavitation has probably occurred, with the formation of a void between the caisson lid and the soil. The tip pore pressure is approximately $-100 \mathrm{kPa}$, indicating cavitation beneath the tip. The relatively small difference between the total load (converted to pressure) and the pressure beneath the lid represents the friction of the sides of the caisson. The pressure difference of about $12 \mathrm{kPa}$ converts to a shear stress of about $2.25 \mathrm{kPa}$ on the inside and outside of the caisson, indicating an $\alpha$ value (shear stress divided by undrained shear strength) of only $0 \cdot 2$. Note also in Fig. 17 that once the tensile load exceeds about $15 \mathrm{kN}$ (corresponding approximately to the estimated friction) the stiffness drops significantly below that encountered during compressive loading. (The initial compressive loading curve is shown in Fig. 17 for comparison, reversed and shifted to the same origin as the pullout.) Experience from model testing in sands (Kelly et al., 2004) suggests that, if the friction value is exceeded during cycling, then rapid degradation of the foundation would occur.

After about $115 \mathrm{~mm}$ of pullout (at time 16:44) the vent to the caisson was opened, at which stage the pressure within the caisson rose to near atmospheric, and extraction occurred at much lower loads.

\section{IMPLICATIONS FOR FULL-SCALE FOUNDATIONS}

The principal purpose of the tests described here is calibration of 'force resultant' theoretical models based on work-hardening plasticity to describe the response of caisson foundations (Houlsby, 2003). However, some simple scaling can be applied to the results of the tests to make some preliminary estimates of the sizes of caissons that would be needed for full-scale wind turbine installations.

A $3.5 \mathrm{MN}$ wind turbine in typical offshore conditions would result in an overturning moment, in extreme conditions, of approximately $120 \mathrm{MN}$ m (Byrne \& Houlsby, 2003). If at this stage it is determined that (say) an acceptable oneway rotation of the foundation is $0.001 \mathrm{rad}$, then the results from Fig. 11 indicate that for a two-way rotation of $0.002 \mathrm{rad}$ a typical mobilised $G / s_{\mathrm{u}}$ value for a soft clay as at 
Bothkennar would be about 175 . Assuming a soil of strength $s_{\mathrm{u}}=60 \mathrm{kPa}$, it can be estimated that a caisson of diameter $26 \mathrm{~m}$ would be required to provide a sufficiently stiff response. The cyclic nature of the applied loading is due principally to the waves, which may have a period of about $10 \mathrm{~s}$. For this case the dimensionless frequency $a$ would be about $0 \cdot 34$, indicating that the dynamic effects would be small, and a quasi-static analysis of the foundation would be justified.

If alternatively an approach based on strength were adopted, then it might be estimated that the $3.0 \mathrm{~m}$ caisson would be able to sustain cyclic moments of about $70 \mathrm{kN} \mathrm{m}$ without significant degradation of response. As the moment capacity scales linearly with the shear strength, and with the cube of the foundation size, it is concluded that a foundation of $22 \mathrm{~m}$ diameter would be required in $60 \mathrm{kPa}$ clay with properties similar to that at Bothkennar. Either a strength or a stiffness criterion therefore results in a foundation of comparable magnitude, but serviceability considerations (i.e. deformations) lead to a requirement for a larger foundation.

If a tetrapod were to be designed, then first the caisson spacing must be determined. For an overturning moment of $120 \mathrm{MN} \mathrm{m}$ and a weight of the structure of say $6 \mathrm{MN}$, then a spacing of $40 \mathrm{~m}$ is needed if tension is to be avoided completely. The maximum loading on an individual caisson would be $3 \mathrm{MN}$, which could be carried in a clay of strength $60 \mathrm{kPa}$ with a factor of safety of about 1.5 by a caisson of diameter $4.0 \mathrm{~m}$. The estimated shear load of $4 \mathrm{MN}$ could also be carried by foundations of this size. It is difficult, however, to assess the influence that such a caisson would have on the stiffness of the structure without more detailed knowledge of the structure itself.

\section{CONCLUSIONS}

A series of field trials of caisson foundations in soft clay are described. The tests are relevant to both monopod and tetrapod designs for foundations for offshore wind turbines. Installation of the caissons was achieved by suction. Highfrequency, low-amplitude cyclic moment tests on a $3.0 \mathrm{~m}$ caisson showed that the response was affected by stiffness, inertial and damping effects. Low-frequency cyclic moment tests on the $3.0 \mathrm{~m}$ caisson indicated a stiff response at low amplitude, with a gradual reduction of stiffness and increase of hysteresis at large amplitude. There was evidence of gapping at the side of the caisson under very large amplitude cycles. Cyclic inclined loading tests on a $1.5 \mathrm{~m}$ diameter caisson also show a reduction of stiffness and increase of hysteresis as load amplitude increases, with a significant reduction in stiffness after the compression to tension boundary is crossed and frictional capacity exceeded. Pullout of the $1.5 \mathrm{~m}$ caisson indicated that ultimate tensile resistance is governed by cavitation beneath the foundation. The tests contribute to the development of design procedures for offshore wind turbines founded on caissons.

\section{ACKNOWLEDGEMENTS}

This research was sponsored by the DTI and a consortium of companies (Fugro Ltd, SLP Engineering Ltd, Garrad Hassan, General Electric Wind Ltd, Vestas and Shell Renewables Ltd). The authors are very grateful to the Royal Society for the Protection of Birds (and in particular to Mike Trubridge) for making the site available for this testing. The authors thank Dr A. Blakeborough for use of the SEMV designed by him, and for advice on interpretation of the SEMV tests.

\section{NOTATION}

$A$ parameter in equation for stiffness variation

a dimensionless angular velocity

$c$ damping coefficient in dynamic analysis

$D$ diameter of caisson

$G$ shear modulus of clay

$H$ horizontal load on caisson

$h$ skirt length of caisson

$k$ rotational stiffness

$M$ overturning moment on foundation

$M_{\max }$ limiting overturning moment

$m$ mass coefficient in dynamic analysis

$N_{\mathrm{c}}$ bearing capacity factor

$R$ radius of caisson

$s_{\mathrm{u}} \quad$ undrained strength of clay

$V$ vertical load on caisson

$v_{\mathrm{S}}$ shear wave velocity in clay

$z$ depth from soil surface

$\alpha$ adhesion factor

$\gamma$ dimensionless damping coefficient

$\theta$ rotation of foundation due to overturning moment

$\mu$ dimensionless mass coefficient

$\rho$ bulk density of clay

$v$ Poisson's ratio

$\omega$ angular velocity of dynamic excitation

\section{REFERENCES}

Bransby, M. F. \& Randolph, M. F. (1998). Combined loading of skirted foundations Géotechnique 48, No. 5, 637-655.

Bye, A., Erbrich, C., Rognlien, B. \& Tjelta, T. I. (1995). Geotechnical design of bucket foundations. Proc. Offshore Technology Conference, Houston, 869-883, OTC 7793.

Byrne, B. W. \& Houlsby, G. T. (2002). Experimental investigations of the response of suction caissons to transient vertical loading. Proc. ASCE J. Geotech. Engng 128, No. 11, 926-939.

Byrne, B. W. \& Houlsby, G. T. (2003). Foundations for offshore wind turbines. Phil. Trans. R. Soc. London Ser. A 361, 2909-2930.

Byrne, B. W. \& Houlsby, G. T. (2004). Experimental investigations of the response of suction caissons to transient combined loading. Proc. ASCE J. Geotech. Geoenviron. Engng 130, No. 3, $240-253$

Byrne, B. W., Houlsby, G. T., Martin, C. M. \& Fish, P. (2002). Suction caisson foundations for offshore wind turbines. Wind Engng 26, No. 3, 145-155.

Byrne, B. W., Villalobos, F., Houlsby, G. T. \& Martin, C. M. (2003). Laboratory testing of shallow skirted foundations in sand. Proceedings of the international conference on foundations, Dundee, pp. 161-173.

Das, B. M. (1993). Principles of soil dynamics. California: Brooks/ Cole.

Doherty, J. P. \& Deeks, A. J. (2003). Elastic response of circular footings embedded in a non-homogeneous half-space. Géotechnique 53, No. 8, 703-714.

Gourvenec, S. \& Randolph, M. F. (2003). Bearing capacity of a skirted foundation under V, H, M loading. Proc. 22nd Int. Conf. on Offshore Mechanics and Arctic Engineering, Cancun, CD-rom, OMAE2003-37014.

Houlsby, G. T. (2003). Modelling of shallow foundations for offshore structures, Invited Theme Lecture. Proceedings of the international conference on foundations, Dundee, pp. 11-26.

Houlsby, G. T. \& Byrne, B. W. (2000). Suction caisson foundations for offshore wind turbines and anemometer masts. Wind Engng 24, No. 4, 249-255.

Houlsby, G. T. \& Byrne, B. W. (2005). Design procedures for installation of suction caissons in clay and other materials. Geotechnical Engineering 158, No. 2, 75-82.

Houlsby, G. T. \& Martin, C. M. (2003). Undrained bearing capacity factors for conical footings on clay. Géotechnique 53, No. 5, $513-520$

Kelly, R. B., Byrne, B. W., Houlsby, G. T. \& Martin, C. M. (2003). Pressure chamber testing of model caisson foundations in sand. Proceedings of the international conference on foundations, Dundee, pp. 421-431.

Kelly, R. B., Byrne, B. W., Houlsby, G. T. \& Martin, C. M. (2004). 
Tensile loading of model caisson foundations for structures on sand. Proc. Conf. Int. Soc. Offshore and Polar Engrs, Toulon, 2, 638-641.

Nash, D. F. T., Powell, J. J. M. \& Lloyd, I. M. (1992). Initial investigations of the soft clay test site at Bothkennar. Géotechnique 42, No. 2, 163-181.

Wolf, J. P. (1994). Foundation vibration analysis using simple physical models. Englewood Cliffs, NJ: Prentice Hall. 